\title{
Analysis of Factors Determining the Credit Rating of Banks from Western European Countries
}

\author{
Dorota Król*
}

The aim of the article is to analyze the determinants affecting credit ratings of banks from Western European countries. On the basis of the literature review, two research hypotheses were put forward. The first of these assumes that the financial indicators related to capital adequacy, asset quality, management quality, profitability and liquidity have a statistically significant effect on the credit rating of the analyzed bank. The second hypothesis indicates that the factors determining the bank's credit rating are the country's macroeconomic indicators and the rating assigned to this country. The analysis used the quarterly data for the years 2010-2017 from the Thomson Reuters database and OECD statistics collected for commercial banks in Western Europe. Based on the prepared data, calculations were carried out using static panel models. The long-term ratings assigned to banks by the two largest rating agencies in the world, i.e. S\&P Long-term Issuer Rating (Foreign) and Moody's Long-term Issuer Rating (Foreign), were used as a dependent variable. Independent variables, on the other hand, include financial indicators and macroeconomic indices of the country where the bank is located and the credit rating of that country.

Keywords: credit rating agency, credit rating, credit risk, financial indicator.

Submitted: 31.01.19 | Accepted: 10.05.19

\section{Analiza czynników determinujących rating kredytowy banków z krajów Europy Zachodniej}

Celem artykułu jest analiza czynników determinujących credit rating banków z krajów Europy Zachodniej. Na podstawie dokonanego przegladu literaturowego postawiono dwie hipotezy badawcze. Pierwsza $z$ nich zaktada, iz istotny statystycznie wptyw na credit rating analizowanego banku maja wskaźniki finansowe dotyczące adekwatności kapitałowej, jakości aktywów, jakości zarzadzania, zyskowności oraz płynności. Druga hipoteza wskazuje zaś, że czynnikami determinującymi rating kredytowy banku sa wskaźniki makroekonomiczne kraju oraz nadana mu ocena ratingowa. Wykorzystano dane kwartalne obejmujace lata 2010-2017, pochodzace z bazy Thomson Reuters oraz statystyk prowadzonych przez OECD zebrane dla banków komercyjnych krajów Europy Zachodniej. Na podstawie przygotowanych danych przeprowadzono obliczenia z użciem statycznych modeli panelowych. Jako zmienna zależna wykorzystano dtugoterminowe ratingi nadawane bankom przez dwie największe agencje ratingowe na świecie, tj. S\&P Long-term Issuer Rating (Foreign) oraz Moody’s Long-term Issuer

\footnotetext{
Dorota Król - mgr, Faculty of Management, University of Warsaw, Poland. https://orcid.org/0000-00029925-5331.

Correspondence address: Faculty of Management, University of Warsaw, 1/3 Szturmowa Street, 02-678 Warsaw; e-mail: dkrol@wz.uw.edu.pl.
} 
Rating (Foreign). Zmienne zależne natomiast obejmuja wskaźniki finansowe oraz wskaźniki makroekonomiczne kraju, będacego siedziba banku oraz credit rating tego kraju.

Słowa kluczowe: agencja ratingowa, credit rating, ryzyko kredytowe, wskaźnik finansowy.

Nadesłany: 31.01.19 | Zaakceptowany do druku: 10.05.19

JEL: C23, G21, G24

\section{Introduction}

Progressive economic development generates changes affecting all areas of activity of each country. This also applies to the financial market, where entities compete with each other in offering new products that provide clients with more and more favorable conditions for acquiring or investing capital. Fundamental importance in this respect, both from the perspective of the entire state and each entity individually, carries the safety of investments and the risks associated with it. Increasingly, the investor not only wants to know such a risk, but also looks for ways to control and reduce it.

Due to the diversity of entities operating in the global financial market (various countries, industries, entities, instruments, financial condition, etc.), there has been the problem of an objective evaluation of such entities in terms of the risk associated with an investment in such entities. The credit rating has become an answer to this type of market need. It is a process involving the estimation of investment risk, the effect of which is the awarding of a rating assessing the credibility of the entity. This has contributed to the creation of specialist companies (rating agencies) that professionally deal with awarding evaluations to specific entities, based on the analysis of their financial credibility (Dziawgo, 2010, p. 7; Wojtas, 2014, p. 32). These notes are particularly used by public trust institutions whose core activity is financial credibility. A significant part of this group of entities are commercial banks using a credit rating both in the process of client bankruptcy risk assessment (standard method) as well as during transactions concluded on the interbank and capital market.

Despite the wave of criticism that has fallen on rating agencies after the recent financial crisis (Grabińska, 2011, pp. 384-386), these institutions still have a significant role in the financial markets. The reason for this is the lack of alternative institutions on the market that specialize in assessing the risk of bankruptcy, which could limit the importance of rating agencies on the financial market. Bearing in mind the above, a number of questions arise regarding the activities of these entities and the process of awarding ratings. This paper analyzes determinants (financial indicators and macroeconomic indicators) affecting the credit rating of banks from Western European countries. Necessary data were obtained from the Thomson Reuters database. Two research hypotheses were put forward. The first of these assumes that the financial indicators related to capital adequacy, asset quality, management quality, profitability and liquidity have a statistically significant effect on the credit rating of the analyzed banks. The second hypothesis indicates that the factors determining the bank's credit rating are the country's macroeconomic indicators and the rating assigned to this country. Static panel models and linear regression using the ordinary least squares method were used to verify the hypotheses.

\section{Literature Review}

The role of credit rating agencies on the contemporary financial market makes them 
a frequent subject of conducted scientific research in which their activities are analyzed from various perspectives. The most popular aspect is their basic activity, that is, awarding ratings. In this process, a large number of factors are taken into account which ultimately affect the value of the note received by the audited entity. It is therefore essential to state which of these factors in fact have the greatest impact on the rating. The dominant number of surveys conducted so far relates to the impact of determinants on the credit ratings of corporate entities. Relatively fewer studies were conducted in the context of banks, which is the main source of interest in the context of this work. The summary of the analysis of articles regarding the factors determining the credit rating in banks is presented in Table 1.

The conducted literature analysis allows for concluding that the basic group of factors included in the research are financial indicators. These contain mainly capital adequacy, profitability, asset quality, quality of management and liquidity ratios (Bissoondoyal-Bheenick \& Treepongkaruna, 2011; Hassan \& Barrell, 2013; Ötker-Robe \& Podpiera, 2010; Poon et al., 2009; Shen et al., 2012). Statistical significance was demonstrated in particular in the case of the ratio of equity to total assets, the rate of return on assets, the level of loan loss provisions and the efficiency ratio. The relationship between the size of the bank and the credit rating assigned to it was also presented. The larger the entity, the higher its financial credibility expressed in the rating note (Hau et al., 2016). Among the analyzed determinants, a group of macroeconomic variables was distinguished, including the GDP growth rate, inflation rate, unemployment rate and the country's credit rating (Bellotti et al., 2011a, 2011b; Bissoondoyal-Bheenick \& Treepongkaruna, 2011; Chodnicka-Jaworska, 2015). A close relationship between the bank's credit rating and the condition of the financial and banking sector was also presented (Chodnicka-Jawroska, 2016). Table 1 contains a summary of selected studies carried out in terms of determinants affecting the credit rating of banks, detailing the scope of the data, the purpose of the research and the determinants used.
On the basis of the literature review, two groups of factors determining the credit rating awarded to commercial banks were distinguished: financial factors and macroeconomic factors. Two research hypotheses were put forward. The first of these assumes that the financial indicators related to capital adequacy, asset quality, management quality, profitability and liquidity have a statistically significant effect on the credit rating of the analyzed bank. The second hypothesis indicates that the factors determining the bank's credit rating are the country's macroeconomic indicators and the rating assigned to this country. Static panel models and linear regression using the ordinary least squares method were used to verify the hypotheses.

\section{Research Methodology and Description of Data}

The presented research was done for 49 banks in Western Europe: Austria, Belgium, France, the Netherlands, Liechtenstein, Germany, Switzerland and the United Kingdom. The analysis was performed on quarterly data for the years 2010-2017 that were collected from the Thomson Reuters database (financial indicators, banks' and countries' credit ratings) and OECD statistics - countries' macroeconomic indicators (OECD, 2018). Based on the prepared data, calculations were carried out using static panel models. The long-term ratings assigned to banks by the two largest rating agencies in the world: S\&P Long-term Issuer Rating (Foreign) and Moody's Long-term Issuer Rating (Foreign $)^{1}$ were used as a dependent variable. Dependent variables, on the other hand, include financial indicators (capital adequacy, asset quality, management quality, profitability, liquidity) and macroeconomic indicators of the country where the bank is located and countries' credit ratings. Due to the qualitative character of dependent variables used in the study, it was necessary to apply a linear method of decomposition of these variables. It allows assigning the appropriate numerical value (quantitative data) expressed in the form of letter codes (qualitative data) to the rating grades. It is assumed that along with an 


\begin{tabular}{|c|c|c|c|}
\hline Authors & Scope & Purpose & Factors \\
\hline $\begin{array}{l}\text { Bissoondoyal-Bheenick E., } \\
\text { Treepongkaruna S. [2011] }\end{array}$ & $\begin{array}{l}\text { commercial banks from the UK (69) and Australia (20) } \\
\text { in 2006-2009 }\end{array}$ & $\begin{array}{l}\text { the analysis of quantitative determinants of bank ratings } \\
\text { (S\&P, Moody's, Fitch) }\end{array}$ & $\begin{array}{l}\text { non-performing loans and leases to loans and leases; charge-offs to loans and leases; non-interest income to gross operating } \\
\text { income; loans to core deposits; liquid assets to assets; capital adequacy ratio; Tier I; ROE, ROA, GDP, inflation }\end{array}$ \\
\hline $\begin{array}{l}\text { Hau H., Langfield S., Marques-Ibanez D. } \\
\text { [2012] }\end{array}$ & $\begin{array}{l}\text { banks from the USA and } 15 \text { countries from the UE } \\
\text { in 1990-2011 }\end{array}$ & $\begin{array}{l}\text { the analysis of the quality of credit ratings assigned to banks } \\
\text { by the three largest rating agencies (Fitch, Moody's, S\&P) }\end{array}$ & $\begin{array}{l}\text { assets; ROA; assets to equity; loans to assets; net profits on trading and derivatives to assets; deposits and short-term } \\
\text { funding to assets; credit growth, index HHI }\end{array}$ \\
\hline Rojas-Suarez L. [2001] & $\begin{array}{l}\text { banks from: Mexico (1993-1995),Venezuela (1993-1994), } \\
\text { Columbia (1981-1988) and Thailand, Korea and Malaysia } \\
\text { (1995-1997). }\end{array}$ & $\begin{array}{l}\text { the influence of financial indicators on the banks' } \\
\text { credit rating (Moody's) and their information potential, } \\
\text { considered in the context of warning against crisis situations } \\
\text { in countries included in emerging markets }\end{array}$ & $\begin{array}{l}\text { traditional indicators (capitalization, equity prices, ratio of net profits to total income, ratio of operating costs to total assets, } \\
\text { liquid assets to total deposits); alternative indicators (implicit interest rate paid on deposits, spread between lending and } \\
\text { deposit rates, rate of loan growth, growth of interbank debt) }\end{array}$ \\
\hline $\begin{array}{l}\text { Van Laere E., Vantieghem J., Baesens B. } \\
\text { [2012] }\end{array}$ & banks from 40 countries in 2001-2011 & $\begin{array}{l}\text { the analysis of the occurrence of split rating on the basis } \\
\text { of notes granted to banks by Moody's and S\&P }\end{array}$ & $\begin{array}{l}\text { In(total assets), loans to deposits; liquid assets to total assets; loan loss provisions to loans; ROE (net income to equity); } \\
\text { common equity to total assets; operating costs to operating income; non-interest income to net income; Z-index, loan } \\
\text { growth; country risk (sovereign rating Moody's and S\&P) }\end{array}$ \\
\hline Shen C., Huang Y., Hasan I. [2012] & banks from 86 countries in 2002-2008 & $\begin{array}{l}\text { the impact of information asymmetry occurring in a given } \\
\text { country on the banks' credit ratings in these countries, based } \\
\text { on long-term credit ratings issued by S\&P }\end{array}$ & $\begin{array}{l}\text { net income to assets (ROA); liquid assets to deposits and short-term funding; capital adequacy ratio; cost to income; loan } \\
\text { loss provisions to net interest revenues; In (total assets) }\end{array}$ \\
\hline Poon W., Lee J., Gup B.E. [2009] & $\begin{array}{l}460 \text { banks from } 72 \text { countries (excluding the United States) } \\
\text { in 1998-2003 }\end{array}$ & $\begin{array}{l}\text { the comparison of the amount of ratings (S\&P) awarded } \\
\text { depending on whether they were solicited and unsolicited } \\
\text { ratings }\end{array}$ & $\begin{array}{l}\text { profitability (net interest margin; net interest revenue to average total assets; pretax operating income to average total } \\
\text { assets; return on average assets (ROA); return on average equity; dividend payout; cost to income ratio), assets quality } \\
\text { (loan loss reserves to gross loans; loan loss provisions to net interest revenue; loan loss reserves to nonperforming loans; } \\
\text { nonperforming loans to gross loans; net charge off to average gross loans; net charge off to net income before loan loss } \\
\text { provisions), liquidity (interbank ratio; loans to total assets; loans to customer and short-term funding; loans to total deposits } \\
\text { and borrowings; liquid assets to customer and short-term funding; liquid assets to total deposits and borrowings), capital } \\
\text { adequacy (Tier } 1 \text { capital ratio; adequacy ratio; equity to total assets; equity to loans; equity to customer and short-term } \\
\text { funding), size (logarithm of book value of total assets; logarithm of book value of trading securities), other variables } \\
\text { (S\&P's long-term bank ratings; S\&P's long-term sovereign ratings) }\end{array}$ \\
\hline Ötker-Robe, I., \& Podpiera, J. [2010] & 29 the biggest European countries in 2004-2009 & $\begin{array}{l}\text { identification of basic variables affecting credit default } \\
\text { swaps }\end{array}$ & $\begin{array}{l}\text { capital adequacy (Tier 1, Tier 2, leverage ratio, z-score), quality (loan-loss provisions to loans, non-performing loans to } \\
\text { loans, loan-loss reserves to nonperforming loans), quality of management (management flexibility, long-term rating), } \\
\text { profitability (net interest income, ROE, ROA), funding position (loan to deposit ratio, share of wholesale funds to liabilities, } \\
\text { short term borrowing to liabilities, liquid assets to assets), market risk (effective GDP growth, GDP volatility) }\end{array}$ \\
\hline Hassan O. A. G., Barrell R. [2013] & $\begin{array}{l}\text { banks from the United States and the United Kingdom } \\
\text { in 1994-2009 }\end{array}$ & $\begin{array}{l}\text { the analysis reflects the risk level of the bank's activity in the } \\
\text { rating assigned to it, based on the notes awarded by the S\&P }\end{array}$ & $\begin{array}{l}\text { size (assets; assets to business volume), leverage (long-term funding minus total equity all to assets; interest-bearing } \\
\text { liabilities to earning assets), profitability (net interest margin, net interest income less loan impairment charges all to earning } \\
\text { assets), efficiency (cost to income, non-interest expenses to assets), liquidity (net loans to total assets, loans to customer } \\
\text { deposits), risk (net charge off or the written-off from loan loss reserves less recoveries to gross loans, a growth of gross loans } \\
\text { of a bank to growth of gross loans), capital adequacy (equity to assets, subordinated borrowing to assets) }\end{array}$ \\
\hline $\begin{array}{l}\text { Bellotti T., Matousek R., Stewart C., } \\
\text { [2011a], [2011b] }\end{array}$ & 681 banks from over the world (90 countries) in 2000-2007 & $\begin{array}{l}\text { the comparison of two models of identifying and predicting } \\
\text { determinants of banks' credit ratings: ordered probit and } \\
\text { logit models and the SVM model (Fitch) }\end{array}$ & $\begin{array}{l}\text { equity to total assets, liquid assets to total assets, In(total assets), net interest margin, operating income to total assets, } \\
\text { operating expenses to total operating income, return on equity }\end{array}$ \\
\hline Chodnicka-Jaworska P. [2016] & 731 banks from European countries in 2005-2015 & $\begin{array}{l}\text { the research on the impact of the banking sector's condition } \\
\text { on banks' credit ratings (Moody's, S\&P) }\end{array}$ & $\begin{array}{l}\text { size of financial system (private loans granted by deposit and credit banks and other institutions to GDP), size of banking } \\
\text { system (deposits of commercial banks to GDP, assets to deposit banks to banking sector assets), efficiency ratio of banking } \\
\text { sector (net interest margin, costs in general, loans to deposits, general costs to gross income), indicator of the structure of } \\
\text { the banking sector (concentration indicator), profitability ratio of the banking sector (ROA, ROE), stability indicator for the } \\
\text { banking sector (z-score index) and index of globalization of the banking sector (deposits of banks from offshore countries to } \\
\text { deposits held with domestic banks, cash flow indicator to GDP, indicator of international loans from non-residents to GDP) }\end{array}$ \\
\hline Chodnicka-Jaworska P. [2015] & banks in 2005-2015 & $\begin{array}{l}\text { the analysis of the impact of macroeconomic factors } \\
\text { on banks credit ratings (Moody's, S\&P) }\end{array}$ & $\begin{array}{l}\text { Moody's: } \\
\text { average real GDP growth, volatility in real GDP, WEF Global Competitiveness Index, national GDP, GDP per capita, } \\
\text { Worldwide Government Effectiveness Index, Worldwide Rule of Law Index, Worldwide Control of Corruption Index, } \\
\text { inflation level, inflation volatility, domestic political risk, geopolitical risk, fundamental metrics, market funding stress, } \\
\text { strength of banking system, size of banking system, funding vulnerabilities, (Current Account Balance +FDI)/GDP, external } \\
\text { vulnerability indicator, net international investment position/GDP } \\
\text { S\&P: } \\
\text { economic structure and stability, macroeconomic policy flexibility, political risk, expansionary phase, private sector credit } \\
\text { growth, equity prices, current account balance and external debt position, private sector debt capacity and leverage, lending } \\
\text { and underwriting standards, payment culture and rule of law, sovereign government credit stress, banking regulation and } \\
\text { supervision, regulatory track error, governance and transparency, risk appetite, industry stability, market distortions, core } \\
\text { customer deposits, external funding, domestic debt capital markets, government role }\end{array}$ \\
\hline
\end{tabular}


increase of the rating note, the number of points awarded to it increases. In this way, the lowest rating is assigned the value -5 , while the highest 100 (Chodnicka-Jaworska, 2017, pp. 52-74), which is presented in Table 2.

Table 2. Decomposition of long-term ratings granted to banks by $S \& P$ and Moody's

\begin{tabular}{|c|c|c|c|}
\hline \multicolumn{2}{|c|}{ S\&P Long-term Issuer Rating (Foreign) } & \multicolumn{2}{|c|}{ Moody's Long-term Issuer Rating (Foreign) } \\
\hline Rating & Code & Rating & Code \\
\hline AAA & 100 & Aaa & 100 \\
\hline $\mathrm{AA}+$ & 95 & Aa1 & 95 \\
\hline AA & 90 & Aa2 & 90 \\
\hline $\mathrm{AA}-$ & 85 & Aa3 & 85 \\
\hline$A+$ & 80 & A1 & 80 \\
\hline A & 75 & A2 & 75 \\
\hline A- & 70 & A3 & 70 \\
\hline $\mathrm{BBB}+$ & 65 & Baa1 & 65 \\
\hline $\mathrm{BBB}$ & 60 & Baa2 & 60 \\
\hline BBB- & 55 & Baa3 & 55 \\
\hline $\mathrm{BB}+$ & 50 & Ba1 & 50 \\
\hline $\mathrm{BB}$ & 45 & $\mathrm{Ba} 2$ & 45 \\
\hline BB- & 40 & $\mathrm{Ba} 3$ & 40 \\
\hline $\mathrm{B}+$ & 35 & B1 & 35 \\
\hline B & 30 & B2 & 30 \\
\hline B- & 25 & B3 & 25 \\
\hline $\mathrm{CCC}+$ & 20 & Caa1 & 20 \\
\hline $\mathrm{CCC}$ & 15 & Caa2 & 15 \\
\hline CCC- & 10 & $\mathrm{Caa} 3$ & 10 \\
\hline $\mathrm{CC}$ & 5 & $\mathrm{Caa}$ & 5 \\
\hline NR & 0 & $\mathrm{C}$ & 0 \\
\hline SD & -5 & WR & -5 \\
\hline $\mathrm{D}$ & -5 & \multirow{2}{*}{ NULL } & \multirow{2}{*}{0} \\
\hline NULL & 0 & & \\
\hline
\end{tabular}

Source: Own elaboration based on Chodnicka-Jaworska (2016, pp. 25-43).

In order to examine the impact of selected factors on the banks' credit ratings, this study used static panel models. This finds its application in case the collected data are characterized by two-dimensionality, i.e. many objects are analyzed in different time periods (Kufel, 2013, p. 173). In this case, these are quarterly data from the period of 10 years for 49 banks from Western Europe. If it is impossible to use panel models, linear regression will be performed using the ordinary least squares method.

The basis for deciding which of these methods should be used (panel models or ordinary least squares - OLS) is the Sargan test. The null hypothesis of this test informs about the correct selection of model instruments (no correlation between the instruments and the random component of the model), while the alternative 
hypothesis indicates the incorrect selection (Pawłowska, 2017, p. 80). In the absence of a basis for rejection of the null hypothesis in the Sargan test, it is reasonable to use panel models. There are two types of panel models: fixed effect models and random effect models. Models of fixed effects (models with artificial variables/ models with decomposition of the absolute term) characterize individual effects with constant parameters. In the case of random effect models (models with error component/models with the decomposi- tion of the random component), individual effects are a random variable with a known distribution. In order to choose between fixed effects and random effects, the test used the Hausman test, which examines the correlation between independent variables and fixed effects. The null hypothesis of this test assumes that group effects are not correlated with independent variables, which indicates the necessity of using the model with the decomposition of the random component. The final version of the model is given by the equation (1) below:

$$
y_{i, t}=\sum_{k=0}^{n} \beta_{k} x_{j, t-k}+\theta_{t} T_{t}+\mu_{j}+\varepsilon_{j, t} n=0
$$

where:

$y_{i, t}-$ S\&P's and Moody's Long-term Issuer Rating (Foreign) for banks from countries from Western Europe

$x_{j, t}-$ a vector of independent variables, i.e.:

$$
\begin{gathered}
x_{j, t}=\left[\operatorname{tier1}_{j, t}, e q_{j, t}, l e v_{j, t}, l l p_{j, t}, e f_{j, t}, \sec _{j, t}, \operatorname{roa}_{j, t}, \operatorname{roe}_{j, t}, o p l_{j, t}, l g_{j, t}, d g_{j, t}, l d_{j, t},\right. \\
\left.G D P_{j, t}, c c r_{j, t}, \text { une }_{j, t}, \text { inf }_{j, t}\right]
\end{gathered}
$$

tier $1_{j, t}$ - capital adequacy ratio Tier1;

$e q_{j, t}$ - equity to total assets;

$l e v_{j, t}$ - financial leverage;

$l l p_{j, t}$ - loan loss provisions to total loans;

$e f_{j, t}$ - efficiency ratio;

$\sec _{j, t}$ - securities to working assets;

nim $_{j, t}$ - net interest margin;

roa $_{j, t}$ - return on assets;

roe $_{j, t}$ - return on equity;

$o p l_{j, t}-$ operating leverage;

$\lg _{j, t}$ - rate of loans growth;

$d g_{j, t}$ - rate of deposit growth;

$l d_{j, t}-$ ratios of loans to deposit;

$G D P_{j, t}-$ GDP growth rate;

ccr $_{j, t}$ - countries' credit rating;

une ${ }_{j, t}$ - unemployment rate;

inf $f_{j, t}-$ inflation rate. 
Table 3. List of independent variables with the direction of impact on the banks' credit ratings

\begin{tabular}{|c|c|c|}
\hline Name of independent variable & Vector & Abbreviation \\
\hline \multicolumn{3}{|c|}{ Capital adequacy } \\
\hline capital adequacy ratio Tier1 & + & tier1 $1_{j, t}$ \\
\hline equity to total assets & + & $\mathrm{eq}_{\mathrm{j}, \mathrm{t}}$ \\
\hline financial leverage & + & $\operatorname{lev}_{\mathrm{j}, \mathrm{t}}$ \\
\hline \multicolumn{3}{|c|}{ Assets quality } \\
\hline loan loss provisions to total loans & - & $1 l p_{j, t}$ \\
\hline \multicolumn{3}{|c|}{ Management quality } \\
\hline efficiency ratio & - & $\mathrm{ef}_{\mathrm{j}, \mathrm{t}}$ \\
\hline securities to working assets & - & $\sec _{\mathrm{j}, \mathrm{t}}$ \\
\hline \multicolumn{3}{|c|}{ Profitability } \\
\hline net interest margin & $+/-$ & $\operatorname{nim}_{\mathrm{j}, \mathrm{t}}$ \\
\hline return on assets & + & roa $_{\mathrm{j}, \mathrm{t}}$ \\
\hline return on equity & + & $\mathrm{roe}_{\mathrm{j}, \mathrm{t}}$ \\
\hline operating leverage & + & $\mathrm{opl}_{\mathrm{j}, \mathrm{t}}$ \\
\hline rate of loans growth & $+/-$ & $\lg _{\mathrm{j}, \mathrm{t}}$ \\
\hline rate of deposit growth & + & $\mathrm{dg}_{\mathrm{j}, \mathrm{t}}$ \\
\hline \multicolumn{3}{|c|}{ Liquidity } \\
\hline ratios of loans to deposit & - & $\mathrm{ld}_{\mathrm{j}, \mathrm{t}}$ \\
\hline \multicolumn{3}{|c|}{ Macroeconomics indicators } \\
\hline GDP growth rate & + & $\mathrm{GDP}_{\mathrm{j}, \mathrm{t}}$ \\
\hline countries' credit rating & + & $\mathrm{ccr}_{\mathrm{j}, \mathrm{t}}$ \\
\hline unemployment rate & + & une $_{\mathrm{j}, \mathrm{t}}$ \\
\hline inflation rate & $+/-$ & $\inf _{\mathrm{j}, \mathrm{t}}$ \\
\hline
\end{tabular}

Source: Own elaboration based on Chodnicka-Jaworska (2016, pp. 25-43).

\section{Analysis of Results}

The analysis of the impact of certain factors on the credit ratings of banks in Western European countries allowed the selection of those determinants which significantly influenced the rating assessment along with the determination of the direction of this impact. For this purpose, it was necessary to determine the significance level $\alpha$, which determines the limit of rejection of the null hypothesis (Gruszyński et al., 2009, pp. 60-61). For each dependent variable, three models were created, differing in the considered independent variables. The first included all selected independent variables, the second included only the bank's financial indicators, while the third included only the impact of macroeconomic factors in the bank's headquarters country and the credit rating assigned to this country.

The first group of models was created to examine the impact of selected factors on the long-term credit rating granted to the banks of Western Europe by the S\&P agency. The first verified group of the banks' financial ratios are capital adequacy ratios. It turns out that each of them (tier1, equity to total assets, financial leverage) has a statistically significant impact on the banks' credit ratings. An increase in these ratios results in a growth in the notes granted by the S\&P. This confirms the com- 
mon approach in which the level of equity determines the financial stability and credibility of the bank. They constitute the basic collateral for the bank and its depositaries in the event of banking risk (mainly credit risk) and the ability to continue operations in the long term. It is therefore reasonable to state that the higher the level of equity, the more credible the bank is and the higher rating it receives. Subsequently, the bank's asset quality was verified, expressed as an index of loan loss provisions to total loans. However, the study did not show any significant impact of this indicator on the level of the dependent variable. This may mean that the level of specific provisions maintained by banks due to performing loans is not a significant element that is taken into account by the rating agency in the assessment process. It can therefore be assumed that this indicator does not reflect the actual financial credibility of the entity, due to its inadequate level, resulting from incorrect classification of credit exposures within the category or a minimum level of specific provisions within this category. Objections as to the essence of the indicator may affect its impact on the final rating of the entity. Statistically significant impact, however, was presented in the case of the efficiency indicator, belonging to the group of management quality indicators. An increase in this ratio leads to a downgrade of the bank's rating, which results from the bank's cost increase in relation to its core banking operations. Higher costs borne by the bank may prove ineffective management and the possibility of transferring them in the long term to bank customers, which in the case of the S\&P agency has a negative impact on the awarded rating. Among the indicators informing about the profitability of the bank, three of them indicate a statistically significant impact on the credit rating level and include: ROA, ROE and operating leverage. While in the case of the return on equity the positive direction of the impact is the expected result (the higher the ROE, the greater the profit earned by the equity unit), the results obtained for ROA and operational leverage may be surprising. The analysis shows that their increase pointedly affects the downgrade of ratings assigned to banks, which is opposite to the expectable direction of impact. However, this may mean that banks have toxic assets. It is a group of complex, speculative assets and, most importantly, providing difficulties during the valuation. The term "toxic" refers to their ability to efficiently "poison" operating entities, resulting in solvency problems. It was the toxic assets that were one of the main elements of the financial crisis in 2007-2009, and some of them had the highest credit ratings. It can therefore be assumed that currently rating agencies do not want to make mistakes from the past and cautiously approach credit ratings on the basis of indicators characterizing the profitability of assets. The liquidity ratio is the banks' last financial indicator verified in this model, which is expressed in the relation of loans to deposits and influences in a statistically significant way an increase of the rating. This means that an increase in credit activity in the bank positively affects the rating assigned to it, which may result from the operating activity of the entity and acquisition of new customers. Next, the significance of macroeconomic indicators of the country in which the bank is located is examined. The survey results indicated that both the country's credit rating and the unemployment rate were statistically meaningful. This designates that the higher the credit rating of a country, the more favorable the macroeconomic environment of the country, which means that the risk of events that could adversely affect the financial stability of the bank is reduced.

The second model was created for S\&P credit ratings, which only took into account banks' financial indicators, whereas the macroeconomic data of the country were omitted. Similarly to the previous model, also here a statistically significant impact of capital adequacy ratios was presented, but only of two: tier1 and financial leverage. However, no significant impact on the rating was found for the equity and the bank's total assets. This may mean more importance of the impact of share capitals (tier1) and the benefits of foreign financing (leverage) on the awarded rating. Statistically significant influence was noticed for the index of loan loss provisions to total loans, whose growth in the opposite direction to the expected one had a positive impact on the bank's rating. In the case of the $\mathrm{S} \& \mathrm{P}$ agency, an increase in the level of specific provisions has a positive impact on the awarded rating, which can be explained as increasing the bank's collateral in the 
event of credit risk for unpaid credit claims. Then, a quality management analysis was carried out, indicating a statistically significant impact of the relationship between the securities and the bank's working assets. This may be due to active investment of financial surpluses in liquid securities (e.g. treasury bonds), which positively affects the bank's credibility. The survey shows that an increase in this indicators positively affects the banks' credit ratings. The ratios informing about the profits generated by the bank also have a significant impact on the dependent variable. Statistically significant was the level of the bank's operating leverage and the growth rate of loans, whose increase resulted in a downgrade of the rating. This may be due to an increase in the bank's lending activity, which directly affects an increase of the entity's credit risk. The least significant impact on the awarded rating is exerted by the ROA ratio and the net interest margin ratio, which in the opinion of the S\&P agency may mean that both the relation of assets to profits and net interest income do not have such a significant impact on the creditworthiness of the entity, giving way to other analyzed indicators.

The analysis of the macroeconomic determinants of S\&P's banks' issuer credit ratings is presented in the third model. The results of this study indicate that if the bank's financial ratios are eliminated, each of the independent variables (GDP growth rate, country's credit rating, unemployment rate and inflation rate) has a significant impact on the rating assessment. This confirms the general assumption that the macroeconomic environment of the entity is an important determinant affecting its financial stability, which in the case of financial institutions is the basis of financial credibility, also affecting the rating assigned to it.

The same as in the case of S\&P's banks' credit ratings estimation method, in the Moody's assessment process three types of models were created. The first one takes into account both the bank's financial ratios and indicators characterizing its macro-environment. The results of this model indicate that both capital adequacy ratios and asset quality parameters do not have a statistically significant effect on the dependent variable. This verification is not so exceptional in the context of the targetspecific indicator, but it is a surprise in the absence of the impact of the level of equity on the bank's credit rating. Especially, it is the value of this balance sheet item that is most controlled by banking supervision authorities. The reason for achieving such results may be the specificity of the constructed model, which in its variables takes into account both the financial indicators of the bank and macro-environment. It can be assumed that in the case of Moody's agency, the influence of the market environment has a greater impact on the financial position of the entity than its own situation. This may be due to the nature of the activities conducted by banks, which, being institutions of public trust, to a large extent are in the center of the market's interest and are strongly correlated with the macroeconomic situation of the country. Therefore, three statistically significant determinants can be distinguished: the inflation rate, the unemployment rate and the credit rating of the country in which the bank has its registered office. The index describing the quality of management regarding the value of securities in relation to working assets was indicated as the first statistically significant factor. An increase in the level of this indicator stimulates the quality of the rating given by the rating agency, as in the case of Moody's agency, it may result from investments carried out by the entity in liquid financial instruments. Another group of indicators whose impact was verified in the described study were profitability ratios. As in the case of capital adequacy ratios, you can also talk about non-obvious results here. Only one of the analyzed factors turned out to be statistically significant - the net interest margin ratio, negatively affecting the level of the issued rating note. This means that an increase in interest income in the rating agencies' assessment may result from an increase in lending, which in turn may result in the appearance of toxic assets in the balance sheet of the bank and an increase in credit risk. Other ratios (ROA, ROE, operating leverage, loan growth rate, deposit growth rate) according to the described research do not have an important impact on the credit rating assigned to banks. The ratio indicating the financial liquidity of the bank - the relation between loans and deposits - has a significant impact and its growth, similarly as in the case of the S\&P agency, positively affects the level of the rating. 
Another model was created based on factors related only to the bank's financial condition. As the first one, a group of indicators regarding capital adequacy was analyzed. In contrast to the previous model, one of them (financial leverage) has a significant positive impact on the dependent variable. This means that after eliminating the macroeconomic factors from the model, one of the capital adequacy ratios is characterized by statistical significance, which confirms the basic assumption about the relationship between the bank's equity and credit rating. From the point of view of the quality of assets, the level of the loan loss provisions to total loans has a statistically significant impact. Similarly as in the case of S\&P, an increase in the index informs about increasing provisions for the event of credit risk resulting from non-payment of non-performing loans, which from the point of view of the bank's operating activity contributes to an increase of its creditworthiness. From the other side, the perspective of management quality, the relationship between securities and working assets has a significant impact too. As with the S\&P agency, the greater their share, the better credit rating banks get. However, the level of efficiency ratio has no statistically significant impact on the dependent variable. Similarly to the first model described for the Moody's agency, in this case too, there was a small inverse relationship between the net interest margin index and the banks' credit ratings. The dependence with the same strength of influence and direction was also found in the case of the indicator characterizing the bank's liquidity, i.e. the relation between loans and deposits.

The last model created for the ratings awarded by the Moody's agency included only the macroeconomic factors of the country where the bank was based. As in the case of S\&P, three of them have a statistically significant impact on the evolution of the dependent variable. The survey results indicate that the GDP growth rate, the country's credit rating and the unemployment rate all have a positive impact on the rating level granted to banks.

\section{Conclusion}

The aim of the study was to verify the hypotheses regarding determinants affecting the credit ratings of banks from Western Europe. The first hypothesis assumed that financial indicators regarding capital adequacy, asset quality, management quality, profitability and liquidity have a statistically significant impact on the credit rating of the analyzed bank. The second hypothesis indicates that the factors determining the bank's credit rating are the macroeconomic indices of the country and the rating assigned to it. To verify the hypothesis, panel models were used and the study was carried out on 49 entities from 8 Western European countries. The independent variable were the long-term ratings awarded to banks by two rating agencies: S\&P and Moody's. On the basis of the literature review, independent variables were selected, among which two basic groups were distinguished: financial ratios characterizing the bank's situation and macroeconomic indices of the country in which the bank is located. For each dependent variable, three versions of the model were created. The first contained both financial and macroeconomic factors, in the second one only the determinants characterizing the bank were analyzed and the third model was intended to examine the impact of only the bank's macroeconomic environment. The results of the study allow for determining the statistical significance of each of these indicators together with determining the direction of its impact on the dependent variable.

The first analyzed group were indicators regarding capital adequacy. A statistically significant impact of all three (tier 1 , equity to total assets, leverage) was noted in the case of ratings given by the S\&P agency, while for the Moody's agency, only the financial leverage ratio was statistically important. The next aspect examined was the quality of the bank's assets, expressed in the relation between the loan loss provisions and the value of total loans. This indicator for both agencies was statistically significant but merely in the second model when the factors regarding only the finan- 


\begin{tabular}{|c|c|c|c|c|c|c|c|c|c|c|c|c|c|}
\hline \multirow{4}{*}{\multicolumn{2}{|c|}{ Independent variable }} & \multicolumn{12}{|c|}{ Dependent variable } \\
\hline & & \multicolumn{6}{|c|}{ S\&P Long-term Issuer Rating (Foreign) } & \multicolumn{6}{|c|}{ Moody's Long-term Issuer Rating (Foreign) } \\
\hline & & \multicolumn{2}{|c|}{ OLS } & \multicolumn{2}{|c|}{ Random effects } & \multicolumn{2}{|c|}{ Random effects } & \multicolumn{2}{|c|}{ OLS } & \multicolumn{2}{|c|}{ OLS } & \multicolumn{2}{|c|}{ Random effects } \\
\hline & & Coef. & $\mathbf{t}$ & Coef. & $\mathbf{t}$ & Coef. & $\mathbf{t}$ & Coef. & $\mathbf{t}$ & Coef. & $\mathbf{t}$ & Coef. & $\mathbf{t}$ \\
\hline \multirow{3}{*}{ 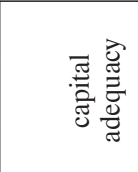 } & capital adequacy ratio Tier1 & 55.7695 & $* *$ & -56.5416 & $* * *$ & & & $-42,8759$ & & $-31,9002$ & & & \\
\hline & equity to total assets & 618.6143 & $* * *$ & 5.8277 & & & & 18,7591 & & 73,4611 & & & \\
\hline & financial leverage & 0.8634 & $* * *$ & 0.6428 & $* * *$ & & & 0,3500 & & 0,5236 & $* *$ & & \\
\hline  & loan loss provision to total loans & -128.2234 & & 228.7423 & $* * *$ & & & $-29,4291$ & & 458,6293 & $* *$ & & \\
\hline \multirow{2}{*}{ 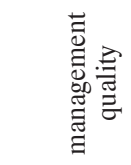 } & efficiency ratio & -4.9856 & *** & -1.0731 & & & & 1,7344 & & 0,0896 & & & \\
\hline & securities to working assets & 2.5943 & & 7.5069 & $* * *$ & & & 27,7037 & $* * *$ & 23,6326 & $* * *$ & & \\
\hline \multirow{6}{*}{ 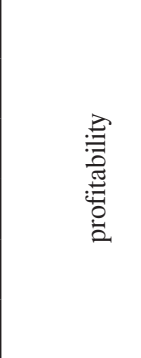 } & net interest margin & -64.7845 & & -80.8310 & $*$ & & & $-141,4461$ & * & $-134,0826$ & * & & \\
\hline & ROA & -4936.314 & $* * *$ & 1116.9970 & $*$ & & & 812,6218 & & 44,5363 & & & \\
\hline & ROE & 307.095 & $* * *$ & -37.1925 & & & & 16,6238 & & 68,0602 & & & \\
\hline & operating leverage & -2.8338 & $* *$ & -2.4735 & $* * *$ & & & $-3,6404$ & & $-2,5500$ & & & \\
\hline & rate of loans growth & 2.3625 & & -13.3044 & $* *$ & & & $-10,9245$ & & $-10,9126$ & & & \\
\hline & rate of deposit growth & -0.1127 & & -0.0370 & & & & 21,0887 & & 21,8773 & & & \\
\hline$\stackrel{?}{:}$ & ratios of loans to deposit & 0.0725 & $* *$ & -0.0146 & & & & 19,5736 & $* *$ & 18,4498 & * & & \\
\hline \multirow{4}{*}{ 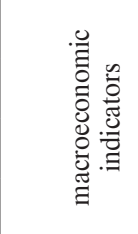 } & GDP growth rate & -138.0358 & & & & 172.0513 & $* *$ & $-48,8709$ & & & & 326,9949 & $* * *$ \\
\hline & country's credit rating & 1.2948 & $* * *$ & & & 0.5327 & $* * *$ & 0,2886 & * & & & 0,7833 & $* * *$ \\
\hline & unemployment rate & 81.2111 & $* *$ & & & 276.8969 & $* * *$ & 119,8480 & $* *$ & & & 262,7326 & $* * *$ \\
\hline & inflation rate & 33.3658 & & & & 285.8969 & $* * *$ & 138,1383 & $* * *$ & & & 46,7357 & \\
\hline \multicolumn{2}{|l|}{ cons } & $-113,0607$ & $* * *$ & 68.0251 & $* * *$ & -4.6135 & & & 5,1416 & 34,3238 & $* * *$ & $-23,0340$ & $* *$ \\
\hline \multicolumn{2}{|l|}{ Sargan } & \multicolumn{2}{|c|}{1,0000} & \multicolumn{2}{|c|}{0.0000} & \multicolumn{2}{|c|}{0.000} & \multicolumn{2}{|c|}{1.0000} & \multicolumn{2}{|c|}{1.0000} & \multicolumn{2}{|c|}{0.0000} \\
\hline \multicolumn{2}{|l|}{ Hausman } & \multicolumn{2}{|c|}{0,0000} & \multicolumn{2}{|c|}{0.9394} & \multicolumn{2}{|c|}{0.3526} & \multicolumn{2}{|c|}{0.6818} & \multicolumn{2}{|c|}{0.6818} & & \\
\hline Test F & & 0,0 & & 0.0 & & 0.0 & & & & 0.0 & & 0.1 & \\
\hline $\mathrm{R}^{2}$ & & 0,5 & & 0.02 & & 0.0 & & & & 0.6 & & & \\
\hline number of & rvations & & & & & & & & & & & & \\
\hline number of $\mathrm{g}$ & & & & & & & & & & & & & \\
\hline
\end{tabular}

Source: Own elaboration. 
cial condition of the bank were verified. In the case of the quality of management, the efficiency ratio turned out to be statistically important just for the ratings given by the S\&P agency. However, the value of securities to working assets was a meaningful relation in the process of granting rating notes by both agencies. The study also verified the influence of profitability indicators on the level of the dependent variable. For S\&P, ROA, ROE and operating leverage were statistically important, whereas in the case of Moody's it was only a net interest margin ratio. A significant impact of the ratio showing the relation between the value of loans and deposits on the ratings granted by the two analyzed agencies was also noted. In relation to macroeconomic indicators, in the case of both dependent variables, a statistically significant effect of the country credit rating and the unemployment rate was found in the models taking into account all independent variables. However, in the model containing only macroeconomic determinants, a statistically significant effect of all the indicators included in the study was demonstrated (except the inflation rate for Moody's).

The aim of the study was to verify the determinants affecting the credit rating of Western European banks. The results of the conducted research confirm the hypothesis put forward in the study that both financial and macroeconomic indicators have a significant impact on the level of credit rating granted to banks by rating agencies. However, this study indicates that this does not apply to all indicators in individual groups and varies depending on the policy adopted by the rating agency. It should also be remembered that the analysis carried out allowed only the determination of the level of significance and the direction of impact of the determinants on the dependent variable. Determining the exact strength of the impact of changes in individual independent variables can therefore be the basis for further testing to verify the examined issue.

\section{Endnotes}

1 Due to the use of quarterly data, the rating was adopted in accordance with the actual situation at the end of a given quarter.

\section{References}

Bellotti, T., Matousek, R., \& Stewart, C. (2011). A note comparing support vector machines and ordered choice models' predictions of international banks' ratings. Decision Support Systems, 51(3), 682-687. doi:10.1016/j.dss.2011.03.008.

Bellotti, T., Matousek, R., \& Stewart, C. (2011a). Are rating agencies' assignments opaque? Evidence from international banks. Expert Systems with Applications, 38(4), 4206-4214.

Bissoondoyal-Bheenick, E., \& Treepongkaruna, S. (2011). An analysis of the determinants of bank ratings: Comparison across ratings agencies. Australian Journal of Management, 36(3), 405-424. doi:10.1177/0312896211426676.

Chodnicka-Jaworska, P. (2015). Credit rating determinants for European countries. Global Journal of Management and Business C, 15(9), 6-18.

Chodnicka-Jaworska, P. (2016). Kondycja finansowa sektora bankowego jako determinanta ratingów kredytowych banków. OPTIMUM - STUDIA EKONOMICZNE, 6(84), 25-43.

Chodnicka-Jaworska, P. (2017). Forma własności banku a credit rating. Bezpieczny Bank, 2(57), 52-74.

Dziawgo, D. (2010). Credit rating na międzynarodowym rynku finansowym. Warszawa: Polskie Wydawnictwo Ekonomiczne.

Grabińska, B., \& Grabiński, K. (2011) Agencje ratingowe a kryzys finansowy na rynku subprime. Zeszyty Naukowe, (10), 384-386. Polskie Towarzystwo Ekonomiczne.

Gruszyński, M., Kuszewski, T., \& Podgórska, M. (2009). Ekonometria i badania operacyjne. Warszawa: Wydawnictwo Naukowe PWN.

Hassan, O.A.G, \& Barrell, R. (2013). Accounting for the determinants of banks' credit ratings. Brunel University of London Economics and Finance Working Paper Series, 13-02.

Hau, H., Langfield, S., \& Marques-Ibanez, D. (2012, October). Bank ratings what determines their quality? EBC Working Paper Series, 1484.

Kufel, T. (2013). Ekonometria. Rozwiazywanie problemów z wykorzystaniem programu GRETL. Warszawa: Wydawnictwo Naukowe PWN.

Ötker-Robe, I., \& Podpiera, J. (2010). The fundamental determinants of credit default risk for European large complex financial institutions (IMF Working Paper vol. WP/10/153).

Pawłowska, M. (2017). Rentowność banków w Polsce w okresie globalnego kryzysu finansowego i kryzysu zadłużenia w strefie euro. Bezpieczny Bank, 2(67), 75-96.

Poon, W., Lee, J., \& Gup, B.E. (2009). Do solicitations matter in bank credit ratings? Results from 
a study of 72 countries. Journal of Money, Credit and Banking, 41, 285-314.

Rojas-Suarez, L. (2001). Rating banks in emerging markets: What credit rating agencies should learn from financial indicator (Institute for International Economics Working Paper No. 01-06).

Shen, C., Huang, Y., \& Hasan, I. (2012). Asymmetric benchmarking in bank credit rating. Journal of International Financial Markets, Institutions \& Money, 22, 171-193.
Van Laere, E., Vantieghem, J., \& Baesens, B. (2012). The difference between Moody's and S\&P bank ratings: is discretions in the rating process causing a split? (RMI Working Paper No. 12/05).

Wojtas, A. (2014). Wiarygodność agencji ratingowych w dobie wzmożonej krytyki ich działalności. Kwartalnik Naukowy Uczelni Vistula, 3(41), 31-44. 